Article

\title{
Sustainable pig and poultry nutrition by improvement of nutrient utilisation - A review
}

\author{
Nachhaltige Schweine- und Geflügelernährung durch Steigerung \\ der Nährstoffnutzungseffizienz - Eine Übersicht
}

\author{
Karl Schedle ${ }^{1}$

\begin{abstract}
${ }^{1}$ University of Natural Resources and Life Sciences Vienna (BOKU), Department for Agrobiotechnology, Institute of Animal Nutrition, Livestock Products and Nutrition Physiology, Muthgasse 11, 1190 Vienna, Austria, e-mail: karl.schedle@boku.ac.at
\end{abstract}

Received: 18 January 2016, received in revised form: 17 February 2016, accepted: 17 February 2016

\begin{abstract}
Summary
In the context of mismanagement of natural resources going with an increasing consumption of protein from animal origin through the world population, one major challenge for the future in animal nutrition is the improvement of its efficiency and hence sustainability. Up to now, a broad range of methods like feed additives or technological treatments have been available to improve the efficiency or the production of pig-derived and poultry-derived food and hence the sustainability in pig and poultry nutrition. Nevertheless, the exact knowledge of the mode of action of these tools is a prerequisite for their successful application. Furthermore, information concerning their impact on the nutrient availability of the different feedstuffs is of great importance, in order to formulate diets that cover the animals' requirements. Diets covering the animals' performance level ovoid undersupplies, which can lead to health problems on the on hand, on the other hand the emissions of nitrogen are kept as low as possible.

As a result, the consumption of natural resources like grains can be considerably reduced and the substitution of regional by-products from the feed and food processing industry like wheat bran, dried distillers grains with solubles or rapeseed meal can be dramatically enhanced in diets for monogastric animals, thus contributing to more sustainable livestock production. By improving the efficiency of the production of animal-derived food, the term "sustainable" remains highly significant. Increasing efficiency plays an important role in ensuring that the resources required for pig and poultry nutrition are foreseeably available. Currently, there is a combination of different tools like feed additives or technological feed treatments the most promising way of improving sustainability in pig and poultry production systems.
\end{abstract}

Keywords: sustainable, animal nutrition, feed efficiency, pig, poultry

\section{Zusammenfassung}

Die ungeeignete Nutzung unserer natürlichen Ressourcen und der gleichzeitig weltweite steigende Konsum an tierischen Eiweiß durch die Weltbevölkerung stellt die Erzeugung von tierischen Lebensmitteln aus Schwein und Geflügel vor große Herausforderungen. Eine effiziente Transformation vom Futter zum tierischen Lebensmittel ist somit unausweichlich.

Momentan stehen uns unterschiedliche „Werkzeuge“ zur Verfügung, wie Futtermittelzusatzstoffe oder eine technologische Futtermittelbehandlung, um die Effizienz und somit die Nachhaltigkeit bei der Erzeugung tierischer Lebensmittel verbessern zu können. Die genaue Kenntnis über die Wirkungsweise dieser „Werkzeuge“ stellt die Grundvoraussetzung zu deren erfolgreichen Einsatz bei der Ernährung von Schwein und Geflügel dar. Darüber hinaus ist deren Auswirkung auf die Nährstoffverdaulichkeit im Futtermittel und somit auch deren Energiegehalt von Bedeutung, um bedarfsgerechte Futterrationen berechnen zu können. Durch eine dem Leistungsniveau angepasste Nährstoffversorgung werden einerseits Unterversorgungen, welche zu gesundheitlichen Problemen führen können, vermieden, andererseits werden die Stickstoffemissionen so gering wie möglich gehalten. Durch den Einsatz der uns zur Verfügung stehenden Futtermittelzusatzstoffe beziehungsweise Futtermittelbehandlungen können regionale industrielle Nebenprodukte wie Weizenkleie, Trockenschlempe oder Rapsschrot in höheren Mengen dem Futter unserer monogastrischen Nutztiere zugesetzt werden. Die Nahrungskonkurrenz zum Menschen kann somit deutlich reduziert werden. Eine Verbesserung der Effizienz vom Futter zum tierischen Lebensmittel beinhaltet somit auch die Definition des Bergriffes „,nachhaltig“. Eine Effizienzsteigerung bei der Produktion von tierischen Lebensmitteln aus Schwein und Geflügel spielt eine wichtige Rolle, um unsere erforderlichen natürlichen Ressourcen zur Ernährung von Schwein und Geflügel vernünftig und voraussehbar verfügbar zu machen. Derzeit scheint eine Kombination verschiedener „Werkzeuge“ wie Futtermittelzusatzstoffe und die technologische Futtermittelbehandlung die vielversprechendste Möglichkeit, eine nährstoffeffiziente und somit nachhaltige Schweine- und Geflügelproduktion sicher zu stellen.

Schlagworte: nachhaltig, Tierernährung, Nährstoffeffizienz, Schwein, Geflügel 


\section{Introduction}

There have been many attempts to define basic approaches to sustainability over the past few decades. Sustainability in terms of resource sufficiency stipulates that a practice is sustainable when the resources needed to proceed with the practice are foreseeably available (Thompson and Nardone, 1999). In the European Union, especially in countries with intensive animal production, producers are not able to ensure that livestock is supplied with nutrients of regional origin, as for example protein (FEFAC 2009). On the other hand, in the special case of trace elements, a physiological oversupply, up to the permitted content of the European Community in feeding practice is well established (Grünewald et al., 2006). Developing diets which cover the animals' requirements, while avoiding excess supply, offers perspectives on feed-efficient production of animalderived food for human consumption, with significantly reduced greenhouse gas emissions (Niemann et al., 2011). Hence, the formulation of diets covering the nutrient requirements of livestock, without oversupplying nutrients, is a strategy for sustainable animal nutrition. Nutrient-deficient diets decline zootechnical performance and animal health in livestock. Thus, knowledge about the nutrient content and its availability in the used feedstuffs is a presupposition to create diets covering the animals' requirements (Schedle et al., 2010a; b). The information about the composition and nutritional value of feeds summarised in tables (Sauvant et al., 2004; NRC, 2012; DLG, 2014) is based on native feedstuffs and does not consider the effects of treatments (e.g. thermal processing or fermentation) on nutrient availability. Nevertheless, knowledge of the effect of feed treatments on the modification of nutrient availability seems to be very important when calculating precise and sustainable diets for pigs and poultry.

The nutrient availability of feedstuffs for pigs and poultry varies widely (Sauvant et al., 2004; NRC, 2012). Possible reasons for such a high degree of fluctuation include all those factors that interfere with the utilisation of nutrients, thus limiting their use particularly in the nutrition of pig and poultry. These factors, e.g. the anti-nutritional factors (ANFs), may cause depressed zootechnical performance and animal health due to a variety of mechanisms including declined amino acid (AA) digestibility, binding various nutrients or damaging the intestinal epithelium (Brenes et al., 2004). Extending the amount of digestible feeds through reduction of anti-nutritive properties could be one possible strategy to achieve the goal of sustainable pig and poultry nutrition.
This review spans a wide range of topics: from the metabolic availability or activity of specific nutrients, partly affected by supplementation of feed additives, to technological treatments. As a result, the consumption of natural feed resources like grains by pig and poultry feed can be considerably reduced without impairing the animals' health or performance. Furthermore, the inclusion of regional industrial by-products like wheat bran, dried distillers grains with solubles (DDGS) or rapeseed meal can be dramatically enhanced for the production of animal-derived products. Hence, the improved efficiency in pig and poultry nutrition focuses on the term "sustainable".

\section{Nutrient utilisation improving feedstuffs, nutrients, additives and feed treatments}

The production of foods from pig or poultry consumes a large amount of cereals. Above all, pigs and poultry directly compete with humans for foods, due to their similar digestive physiology. Hence, the reduction of cereals in diets for pigs and poultry is very important from a sustainability point of view. Knowledge about the mode of action of feed additives, as well as technical treatments that enable an effective application of the feedstuffs used, is a prerequisite for sustainable, increasingly efficient pig and poultry nutrition.

\subsection{Physiologically active nutrients}

There are many different substances with physiological action (e.g. dietary fibre, secondary plant metabolites, vitamins, amino acids (AA)). During the production process, the fibre content in most industrial by-products increases. In terms of sustainability, attention should be given to an enhanced use of industrial by-products for the production of food of animal origin. Thus, the following chapter will focus on dietary fibre.

\section{Dietary fibre}

Most industrial by-products from flour, biofuel, or vegetable oil production contain a high amount of dietary fibre. Knowledge about the physiological action of the different fibre sources, in combination with the correct information on the available nutrient contents, enables the inclusion of higher amounts of such feedstuffs in diets for pig and poultry (Kluth and Rodehutscord, 2006; Schedle et al., 2010a; b; 2012). 
Dietary fibre represents a group of feed constituents originating from plants. In addition to lignin, they consist of non-starch polysaccharides (NSP) and so-called resistant oligosaccharides, analogous carbohydrates and substances associated with the NSP and lignin complex in plants. One of the most prominent properties of fibre is that it is not hydrolysable by digestive enzymes released from the organism into the gut lumen. Consequently, the so-called resistant starch also has to be classified as a dietary fibre (AACC, 2001). Prebiotic carbohydrates are defined as food ingredients that selectively stimulate the growth and activity of bifidobacteria and lactobacilli in the gut. Therefore, they have health benefits (Gibson and Roberfroid, 1995; Cummings and Macfarlane, 2007). Furthermore, prebiotic carbohydrates may also have additional, less specific benefits because they are fermented in the large intestine (Cummings and Macfarlane, 2007). Nevertheless, from a physiological point of view, prebiotic carbohydrates can be classified as dietary fibre.
Dietary fibre varies widely with regards to different botanical origins, as well as within plant and cell compartments, and physical properties, such as the surface of the particles. Furthermore, their fermentation suitability may additionally affect the living conditions of intestinal microbiota and hence the entire digestive process to a significant extent (Knudsen, 1997; Wenk, 2001; Montagne et al., 2003). Consequently, many studies addressing the term fibre in general may produce different and sometimes contradictory results (Montagne et al., 2003). In this context, a more clear description of fibre is necessary. Figure 1 and Table 1 show a classification of the different dietary fibre constituents, as well as a scheme of carbohydrate fractions. Although dietary fibre is not considered a nutrient per $s e$, it shows secondary actions on the digestion process in different parts of the organism (Bach Knudsen, 2001; Wenk, 2001; Montagne et al., 2003). Action starts with passive parameters like feed intake, and continues to affect gut microbiology and its metabolites, tissue morphology,

Table 1. Constituents and classification of dietary fibre [according to Bach Knudsen (1997), AACC (2001), Mussato \& Mancilha (2007)]

Tabelle 1. Bestandteile und Einteilung der Faserfraktionen [nach Bach Knudsen (1997), AACC (2001), Mussato \& Mancilha (2007)]

\begin{tabular}{|c|c|c|}
\hline Category & Monomers & Sources \\
\hline \multicolumn{3}{|l|}{ Polysaccharides } \\
\hline Resistant starches & Glucose & $\begin{array}{l}\text { Partly milled grains and seeds, raw potato, banana, } \\
\text { heat-treated starch products }\end{array}$ \\
\hline \multicolumn{3}{|l|}{ Non-starch polysaccharides } \\
\hline Cellulose & Glucose & Most cereals and legumes \\
\hline Mixed linked $\beta$-glucans & Glucose & Barley, oats, rye \\
\hline Arabinoxylans & Xylose, arabinose & Rye, wheat, barley \\
\hline Arabinogalactans & Galactose, arabinose & Cereal coproducts \\
\hline Xyloglucans & Glucose, xylose & Cereal flours \\
\hline Rhamnogalacturans & Uronic acids, rhamnose & Pea hulls \\
\hline Galactans & Galactose & Soy bean meal, sugar beet pulp \\
\hline (Pectins) & Uronic acids, rhamnose & Apple, sugar beet pulp \\
\hline \multicolumn{3}{|l|}{$\underline{\text { Resistant Oligosaccharides }}$} \\
\hline$\alpha$-Galacto-oligosaccharides & Galactose, glucose, fructose & Soy bean meal, peas, rapeseed meal \\
\hline Fructo-oligosaccharides & Fructose, glucose & Cereals, feed additives, Jerusalem artichokes \\
\hline Transgalacto-oligosaccharides & Galactose, glucose & Feed additives, milk products \\
\hline$\underline{\text { Lignin }}$ & Phenolic macromolecule & Cotton seed, cereal bran, pine pollen, ligno-cellulose \\
\hline \multicolumn{2}{|l|}{ Substances associated with the NSP and Lignin } & \\
\hline Waxes, phytate, cutin, saponins, suberin, tannins & several components (e.g. furan rings, hydroxy fatty acids) & Leaves, cereals \\
\hline
\end{tabular}




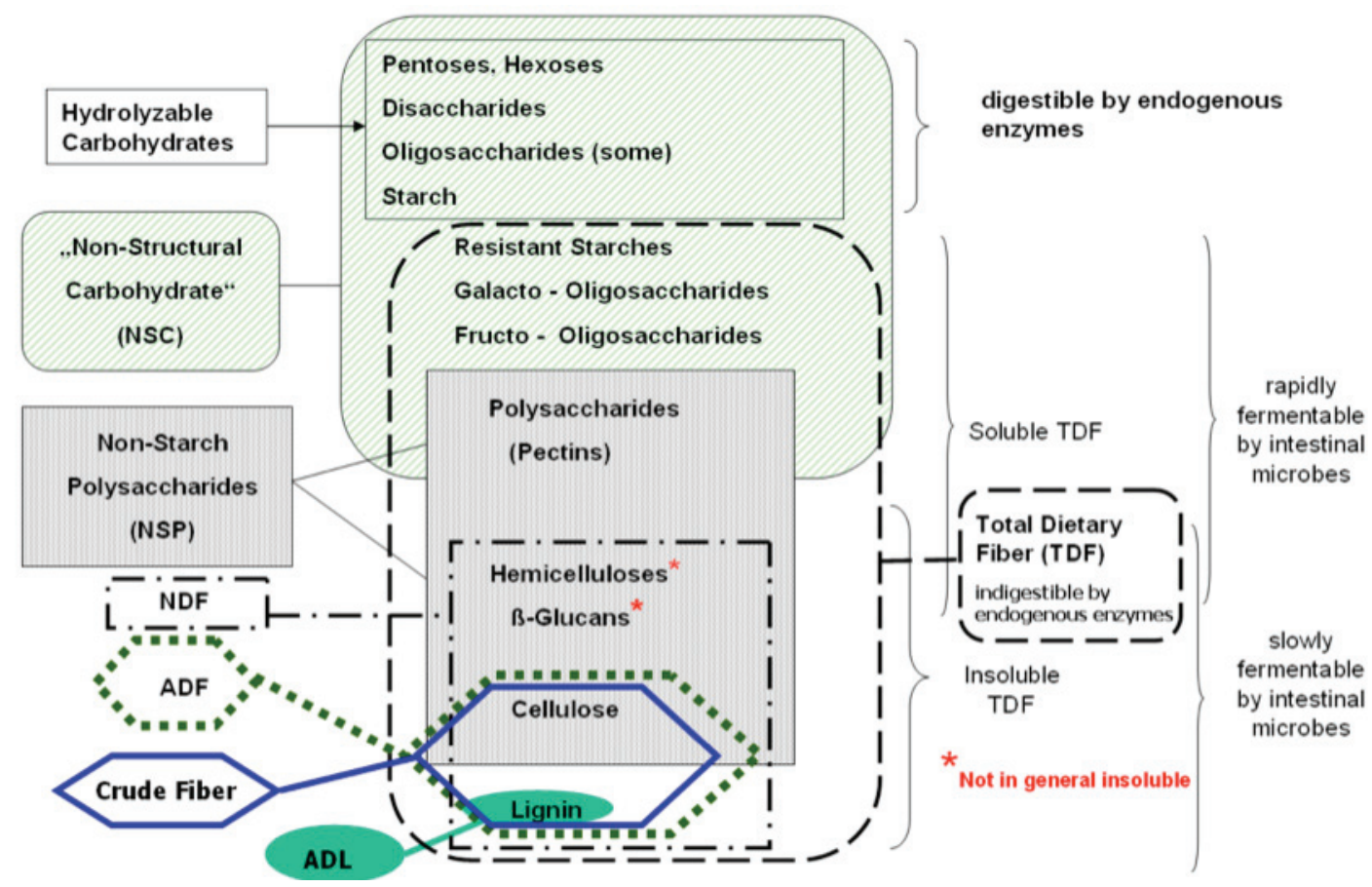

Figure 1. Scheme of carbohydrate fractions, modified according to AOAC (2000)

Abbildung 1. Schematische Darstellung der Kohlenhydratfraktionen nach AOAC (2000)

immunology, and finally zootechnical performance (Wenk, 2001; Montagne et al., 2003; Schedle et al., 2008b). In general, dietary metabolisable energy content decreases with higher contents of dietary fibre (Hador and Wenk, 1996). Pigs utilise diets containing high amounts of dietary fibre to a greater extent than poultry (Sauvant et al., 2004), because the larger digestive tract of pigs in relation to body weight results in both a much higher presence of intestinal microbiota and increased fermentation capacity of dietary fibre (Bedford and Schulze, 1998; Schedle et al., 2008a; Humer et al., 2014). Therefore, commercial diets for poultry need to be highly digestible and low in dietary fibre.

Intensive research dealing with animal nutrition and dietary fibre started in the middle of the last century. Nevertheless, recent research has evaluated the effects of dietary fibre on the development of the gastrointestinal tract (GIT), nutrient retention and growth performance in depth (GonzálezAlvarado et al., 2008; Schedle et al., 2008a; b; Amerah et al., 2009; Metzler-Zebeli et al., 2010; Schedle et al., 2012; Schedle et al., 2014). Furthermore, there is ongoing research into evaluating the mode of action of dietary fibre.

It is well known that additional insoluble dietary fibre (in nutritive amounts) tends to increase voluntary feed intake of pigs (Jørgensen et al., 1996; Schedle et al., 2008b). Fibre addition raises gut fill and in the case of viscosity increases fibre gut volume, which in turn is probably associated with an overall increase of viscera organ weight (Jørgensen et al., 1996; McDonald et al., 2001). Consequently, fibre intake may raise total dry matter (DM) consumption capacity and thus indirectly body weight gain. However, study designs showing a balanced metabolisable energy content and an increased fibre content between treatments, did not observe differences in feed intake or viscera organ weight (Widmer et al., 2008; Schedle et al., 2010b; 2012; Kraler et al., 2015). Regarding feed intake, similar results were observed for poultry (Vranjes and Wenk, 1995; Hador and Wenk, 1996; Schedle et al., 2010; 2014). Hence, observed differences in feed intake can be associated with differences in metabolisable energy contents or variation in digesta viscosity of diets. In general, dietary fibre affects the digestive process due to different modes of action (Wenk, 2001; Montagne et al., 2003). In this context, we must distinguish between soluble and insoluble fibre. Within soluble fibre, further classification separates fibre sources which increase viscosity of the intestinal contents (e.g. pectins in sugar beet pulp) from those with no effect on physicochemical and rheological properties (e.g. inulin as oligofructose). The insoluble category can be divided into insoluble and slowly fermented fibres (wheat 
bran, soya bean hulls) or insoluble and unfermentable ones without effects on physicochemical properties, with the exception of increasing the faecal bulk volume (maize cobs, linseed hulls) (Van Nevel et al., 2006).

Viscous dietary fibre delays stomach emptying, satiety, and increases transit time. In the small intestine, this type of fibre creates a "cage effect" upon other dietary particles possibly containing valuable nutrients like proteins or fat, thus impairing access to digestive enzymes and causing an overall decrease in digestibility (Montagne et al., 2003). This kind of dietary fibre is considered to reduce villi length in the jejunum and ileum, which is positively correlated with germ counts of potential pathogens (Drochner et al., 2004).

Dietary composition may influence the carbohydrate structures of the mucosal and mucin glycoconjugates, with marked consequences for the adherent microflora (Kelly et al., 1994). Supplementation of insoluble dietary fibre may reduce transit time and vulnerability of the intestinal tissue to attacks from potential pathogens (Montagne et al., 2003). A possible reason for this action seems to be a decrease in adherence possibilities for pathogen germs due to the alteration of the glycoproteins in the mucosa (Drochner et al., 2004). Schedle et al. (2008a; b) reported from a reduction of pathogen germs affected by insoluble dietary fibre, which was also confirmed by the decrease in pro-inflammatory marker genes in the hindgut. In contrast to soluble dietary fibre, insoluble fibre may increase intestinal size and hence stimulate the release of brush border enzymes, as well as increasing adsorption surface (Pluske et al., 1997). In the hindgut, water holding capacity (WHC) will be maintained by insoluble dietary fibre. Hence, mostly insoluble dietary fibre may increase $\mathrm{WHC}$ and produce more faecal volume (Glitsø et al., 1998).

Dietary fibre addition may decrease apparent digestibility of DM and crude protein (Kreuzer et al., 1991; Sauer et al., 1991; Hansen et al., 2006), because in terms of bacterially fermentable substrates, the bacterial growth in the hindgut is promoted. Furthermore, it reflects the transformation of mainly $\mathrm{NH}_{3}$, into bacterial protein and hence the increase in faecal $\mathrm{N}$ excretion (Kreuzer et al., 1991; Hansen et al., 2006). Such reduction in nutrient digestibility can also appear as a result of increasing insoluble dietary fibre supplementation (Wenk, 2001).

During the process of digestion in the small intestine, the content of highly digestible components (e.g. protein, fat, sugars, starch) decreases and the content of hardly digestible material, such as fibre, increases proportionally. This material, mixed with endogenous secretion, enters the hindgut and is substrate to a number and diverse range of microbes (Bach Knudsen and Hansen, 1991; Kreuzer et al., 1991). Fermentation of fibre is much higher for cell material from non-lignified materials than for lignified materials (Bach Knudsen and Hansen, 1991; Wenk, 2001). Consequently, soluble dietary fibre represents the main source of fermentable material in the large intestine (Bach Knudsen and Hansen, 1991; Kreuzer et al., 1991). The most important products of microbial fermentation are SCFA, $\mathrm{H}_{2} \mathrm{O}$, various gases $\left(\mathrm{CO}_{2}, \mathrm{H}_{2}, \mathrm{CH}_{4}\right)$ and bacterial protein (Montagne et al., 2003). Between $95 \%$ and $99 \%$ of total SCFA produced in the GIT are absorbed before reaching the rectum (Van Engelhardt et al., 1989; Montagne et al., 2003). These SCFA still contain considerable amounts of energy providing up to $15-24 \%$ of maintenance requirements for pigs (Montagne et al., 2003). SCFA are an important source of energy to the colonocytes, with butyric acid being the primary source (Williams et al., 2001). Acetate acts as an energy substrate for muscle tissue and propionate may be transformed into glucose in the liver (Montagne et al., 2003). As carbohydrate sources become depleted due to microbial degradation and utilisation, fermentation becomes more and more proteolytic. This may lead to the formation of potentially toxic metabolites like $\mathrm{NH}_{3}$ or biogenic amines (Williams et al., 2001). Biogenic amines can influence feed intake by triggering hypothalamic reactions along the serotonin pathway (Eder et al., 2003).

Special kinds of dietary fibre appear to increase protection against enteric infections with pathogenic germs, and/or infections and subsequent diseases in monogastric mammals (Montagne et al., 2003). In the case of insoluble dietary fibre, a reduced proliferation of E.coli was reported post-weaning (Bertschinger et al., 1979). Hence, dietary fibre seems to exert a protective effect against major problems of intensive pig production, like diarrhoea or ulcers (Sanders et al., 2012; Schedle et al. 2008; 2012).

In summary, in a nutritionally fibre-rich balanced diet with low viscosity-increasing effect, no decrease in performance can be expected for pigs and broilers (Schedle et al., 2010; 2012; 2014; Kraler et al., 2015). Furthermore, moderate amounts of insoluble dietary fibre can improve the performance and health status of pigs and poultry (Montagne et al., 2003; Schedle et al., 2008a; González-Alvarado et al., 2010). From a sustainability perspective, using high amounts of such fibre-rich feedstuffs would be desirable, in order to reduce the strong competition for food between humans and monogastric livestock. 


\subsection{Feed additives}

Animal nutrition is currently targeting methods to improve mineral and nutrient digestibility, through the use of e.g. diverse feed additives. Feed additives are products used in animal nutrition in order to improve the following: the quality of feed, the quality of food of animal origin, or the animals' performance and health. In total, they show great potential to improve the nutritional value of feedstuffs (Bedford and Schulze, 1998; Roth and Kirchgessner, 1998; Gaggia et al., 2001; Windisch et al., 2008; Humer et al., 2014). According to Regulation (EC) No 1831/2003, feed additives are subject to an authorisation process before they are commercially available. They are put on the market only if scientific evaluations have shown that they have neither harmful effects on human and animal health, nor on the environment. Authorisations are granted for specific animal species, specific conditions of use and for a period of ten years. The feed additives category includes many substances or products, with a variety of modes of action. Hence, the EC classified the additives into functional groups. Additives are classified into the following categories according to (EC) No 1831/2003:

- Technological additives (e.g. preservatives, antioxidants, emulsifiers, stabilising agents, acidity regulators, silage additives)

- Sensory additives (e.g. flavours, colorants)

- Nutritional additives (e.g. vitamins, minerals, AA, trace elements)

- Zootechnical additives (e.g. digestibility enhancers, gut flora stabilizers)

- Coccidiostats and histomonostats

Feed additives listed in the category "zootechnical additives" show the most potential to improve zootechnical performance and therefore to increase efficiency. Within this category, again, substances with different modes of action such as organic acids, essential oils, microorganisms or enzymes are listed [(EC) No. 1831/2003]. Hence, this category was subdivided as follows:

- Digestibility enhancers (e.g. enzymes)

- Gut flora stabilisers (e.g. microorganisms)

- Other zootechnical additives (e.g. organic acids and their salts, essential oils)

The present review focused on feed additives in the "zootechnical additives" category, including all three subcategories, in order to improve pig and poultry efficiency.

\section{NSP-hydrolysing enzymes}

As shown in Figure 1 and Table 1, NSP fraction constitutes the majority of dietary fibre. Hence, the possible modes of action, as well as positive or negative effects on the gastrointestinal physiology, are explained in Section 2.1. dietary fibre. Generally, the overall effect of NSP-hydrolysing enzymes should result in an improvement of performance parameters, a reduced occurrence of sticky faeces, as well as an increase of metabolisable energy, by abolishing the viscosity-increasing effect of $\beta$-glucans and arabinoxylans and eliminating the nutrient encapsulating effect of cell walls (Bedford and Schulze, 1998; O’Neill et al., 2014). According to O'Neill et al., (2014), NSP-hydrolysing enzymes can be divided in three categories:

- single-component products

- blended products

- "enzyme cocktails"

Single-component products are marketed by emphasising their main products like $\beta$-glucanase or arabinoxylanase. Nevertheless, the final product of single component products will include some enzyme side activities, which may or may not be promoted by the manufacturer. However, in modern products the target enzyme activity is both over-expressed and has characteristics such as thermostability, which the side activities do not possess, rendering the product virtually a single-component product in a heat treated feed. Blended products contain two or three pronounced activities, which are produced individually and in a blended manner. Therefore, they may have two or three primary activities which, individually, are subject to the same considerations as single-component products. Enzyme cocktails are the products of a single fermentation that produces a multitude of activities. It is unlikely that all are quality controlled or promoted by the manufacturer (O'Neill et al., 2014). The modes of action of the different NSPases are well known and were reviewed by Bedford and Schulze (1998) and O'Neill et al. (2014), and will not be further mentioned in this review.

Reports about positive effects on zootechnical performance as a result of NSPases in fibre-rich or rather NSP-rich diets for pigs and poultry are contrasting (Bedford et al., 1992; Vranjes and Wenk, 1995; Emiola et al., 2009; Widyaratne et al., 2009; Boguhn and Rodehutscord, 2010; Ayoade et al, 2012; Schedle et al., 2012; 2014). A possible explanation for the absence of improving effects on zootechnical performance in the studies of Schedle et al. $(2012 ; 2014)$, 
which were carried out with mostly insoluble fibre-rich/ NSP-rich DDGS, could be the inclusion of similar NSPdegrading enzymes in the production process of the DDGS product which were used. Additional reasons for the absence thereof could be a lack of the hydrolysable substrate or in the case of feedstuffs high in $\beta$-glucans, such as barley, a greater extent of endogenous enzyme denaturation takes place at the ileum (Dierick and Decuypere, 1994; Högberg and Lindberg, 2004). In general, it has been observed that the activity of $\beta$-glucanases and other exogenous enzymes is lower in pigs than in poultry (Medel et al., 2002). Furthermore, the optimum dietary concentration of NSPases may depend on the variety of grain utilised in the animals' diet (Bedford, 1995).

In summary, the application of NSP-hydrolysing enzymes in NSP-rich diets should be applied carefully, to make sure its application is successful and to ensure sustainable and efficient nutrition for pigs and poultry.

\section{Phytases}

In contrast to NSP-hydrolysing enzymes, results with phytase are not subject to such extreme variations. Nevertheless, they are inconsistent with respect to the degree to which $\mathrm{P}$ can be replaced by this enzyme (Bedford and Schulze, 1998). The majority of $\mathrm{P}$ in plant-derived feedstuffs occurs in the form of phytic acid (myo-inositol$1,2,3,4,5,6$-hexakisphosphate). Based on the negative charge of this inositol phosphoric ester, phytic acid forms a complex salt called phytate, with divalent metal cations such as calcium, iron, zinc, magnesium and manganese. Therefore, it inhibits the absorption of these minerals (Kornegay, 2001). The enzyme phytase catalyses the stepwise hydrolysis of phytate. With respect to livestock nutrition, there are four possible sources of this enzyme available for the animals: endogenous mucosal phytase, gut microfloral phytase, plant phytase and exogenous microbial phytase. As endogenous mucosal phytase in monogastric organisms appears incapable of hydrolysing sufficient amounts of phytate-bound $\mathrm{P}$, the common method to improve $\mathrm{P}$ digestibility in plant-derived feedstuffs for pigs and poultry is supplementation with exogenous phytase (Selle and Ravindran, 2008). The mode of action of phytases was recently reviewed by Humer et al. (2015b).

Improved P digestibility reduces the requirement for Psupplementation in swine and poultry diets (Humer et al., 2013; 2015b), which lowers costs and saves the natural resource P. Furthermore, the amount of P excreted by the animal is reduced (Leytem and Thacker, 2010; Humer et al., 2013). Both reduced use of $P$ in animals' diets and the lower output as a result of phytase supplementation significantly contributes to sustainable monogastric animal and poultry nutrition.

In addition to the supplementation of microbial phytase, processing techniques (see chapter 2.3 for details) are alternative approaches to reducing phytate content. Thus, techniques such as germination, soaking or fermentation enable activation of naturally occurring plant phytase. Lactic acid bacteria obviously produce microbial phytases during fermentation (Lopez et al., 2000). Thus, they are able to promote phytate degradation (DeAngelis, 2003). Furthermore, the acidification of the diet can lead to activation of endogenous plant phytases (Kozlowska et al., 1996).

\section{Probiotics}

According to Parker (1974), probiotics are defined as organisms and substances which contribute to intestinal microbial balance. Fuller (1989) improved Parker's definition of probiotics with the following distinction: "A live microbial feed supplement which beneficially affects the host animal by improving its intestinal microbial balance." The most commonly used probiotics are yeasts and bacteria targeting the hindgut (Chaucheyras-Durand \& Durand 2010). Kabir (2009) reviewed the mode of action of probiotics as follows:

- maintaining normal intestinal microflora through competitive exclusion and antagonism;

- altering metabolism by increasing digestive enzyme activity and decreasing bacterial enzyme activity and $\mathrm{NH}_{3}$ production;

- improving feed intake and digestion;

- stimulating the immune system.

Considerable research efforts have been devoted to the determination of effects of probiotics on growth performance, as well as their potential mode of action (Huang et al., 2004; Canibe et al., 2008; Chaucheyras-Durand and Durand, 2010; Mair et al., 2010a; b). To a great extent, the effects of probiotics are influenced indirectly by alterations in microbial fermentation patterns in the GIT and by the strains themselves (Domeneghini et al., 2006). This includes modifications of the intestinal microbial population, the morphology and transport properties of the in- 
testinal mucosa. In the special case of poultry, a reduction of colonisation and shedding of Salmonella and Campylobacter was observed when a number of probiotics were applied (Nisbet, 1998; Netherwood et al., 1999; Fritts et al., 2000). Also, in diets for weaning piglets, a reduction in the incidence of post weaning diarrhoea was reported (Simon, 2010). Furthermore, modifications of the immune system are discussed. The hypothesis that probiotics affect gut morphology and immune parameters could be supported by Mair et al. (2010b). Hence, the effects observed occurred along the entire GIT with no restriction to the large intestine.

Nevertheless, regarding zootechnical performance in pigs, Simon (2010) concluded from both their own data and the published data, that the effects of probiotics on performance are rarely significant. More promising effects of probiotics on performance were reported for poultry (Mountzouris et al., 2007; 2010; Kabir, 2009).

\section{Synbiotics}

According to Schrezenmeir et al. (2001), synbiotics refer to products that contain both probiotics and prebiotics. Because the word alludes to synergism, this term should be reserved for products in which the prebiotic compound selectively favours the probiotic compound. However, the studies of Mair et al. (2010a; b) showed that several investigated parameters like gut morphology, immune parameters or $\mathrm{pH}$-value showed no synbiotic effect, but there were distinct individual effects of inulin used as a prebiotic and a multispecies probiotic formulation. Hence, interactions between several experimental factors were observed, showing the antagonistic effects of the synbiotic group (Mair et al., 2010a; b). This indicates that either inulin or the probiotics showed distinct individual effects, which could not be used to predict the results in the synbiotic group. The results from Mair et al. (2010a; b) are supported by Roller et al. (2004). However, further understanding of the underlying mechanisms of prebiotics and/or probiotics, in particular, their interactions with different feed matrixes is still required, in order to significantly improve the animals' performance and hence their sustainability.

\section{Phytogenic products}

The class of phytogenic feed additives refers to plant-derived products used in animal feeding to improve the perfor- mance of agricultural livestock. These products have recently gained increasing popularity, especially for use in singlestomached animals. Hence, numerous mixtures of plants and their extracts have lately entered the commercial swine and poultry feeding sector. Their potential mode of action was thoroughly reviewed by Windisch et al. (2008). Several of these phytogenic blends or substances have emerged as showing promise in improving productivity, either through their antioxidant and antimicrobial properties, improvement in diet palatability, improvement of gut function (digestive secretion, absorptive capabilities, or changes to barrier functionality), suppression of pathogen virulence and/or tissue recovery after damage (Windisch et al., 2008). Nevertheless, contrasting results regarding performance show the necessity for greater knowledge and more mechanistic approaches to this subject to fully understand where and how exactly plant-derived feed additives act in monogastric livestock and poultry. Reports from literature show a similar mode of primary action compared to antibiotic growth promoters in piglets, namely, an overall antimicrobial effect in the GIT (Cho et al., 2006; Kroismayr et al., 2008a; b; Fang et al., 2009). The investigations of Humer et al. (2015a) showed less pronounced antibiotic effects. Possible explanations could be that the positive effects of the tested dosages of the phytogenic feed additive would have been more pronounced under less hygienic environmental conditions, higher dosages of the product or when using a less digestible diet (Amad et al., 2011; Humer et al., 2015a). Also, the reports about an immune-stimulating effect affected by such phytogenic substances are contrasting (Böhmer et al., 2009; Hoffmann-Pennesi and Wu, 2010; Najafi and Torki 2010, Mueller et al., 2013; Humer et al., 2015a). Hence, the conflicting results regarding different modes of action in recently published studies shows the need for further investigations to ensure a precise use of these kinds of feed additives in monogastric animal and poultry nutrition.

\section{Organic acids}

Organic acids (C1-C7) are natural constituents of some feeds which occur in the body metabolism and the GIT. They show a similar mode of action in the intestine as antibiotic growth promoters (Roth and Kirchgeßner, 1998; Partanen and Mroz, 1999). Furthermore, it is generally considered that dietary organic acids or their salts

- lower gastric $\mathrm{pH}$;

- increase activity of proteolytic enzymes; 
- increase gastric retention time of digesta;

- improve protein digestion.

Organic acids may also positively influence gut morphology and therefore absorptive capacity, which could contribute to improved protein, energy and/or mineral absorption. Organic acids are also known to be effective preservatives which protect stored foods and feeds against undesirable bacterial or fungal growth (Roth and Kirchgeßner, 1998; Partanen and Mroz, 1999). The growthpromoting and hence the efficiency-increasing effects of organic acids may be due to increased nutrient and energy digestibility as well as retention, alteration of the intestinal microflora and metabolites in the GIT. In addition to their well-established growth-promoting and energy-delivering effects, special kinds of organic acids like benzoic acid have the potential to reduce $\mathrm{NH}_{3}$ emission from excrement by reducing urinary $\mathrm{pH}$, without harming the animal (Partanen and Mroz, 1999; Bühler et al., 2006; Plitzner et al., 2006). This is explained by the fact that urease oxidises free $\mathrm{NH}_{3}$ only at high $\mathrm{pH}$ values (Pommerening-Röser and Koops, 2005). This is of particular importance in sustainable animal nutrition, as the negative effects of $\mathrm{NH}_{3}$ on animals and the environment can be reduced.

In summary, most of the substances or additives explained in Chapter 2.2. showed a positive effect on performance in the postnatal and juvenile phase of the animals (Overland et al., 2000; Plitzner et al., 2006; Awad et al., 2008). Furthermore, poor hygienic environmental conditions can enhance the alleged effects of the additives used (Kommera et al., 2006; Humer et al., 2015a). This is very important for their application under practical conditions, because the high standards of hygienic status and feed formulation at research facilities are well known.

\subsection{Technical treatment of feedstuffs and their effect on nutrient availability}

Feed treatments based on a hydro-thermal technology like pelleting, expanding or extruding are well established in the feed industry. Feed processing further adds to the cost of feeds. However, it provides an opportunity to improve the animals' performance (Nolan et al., 2010; Abdollahi et al., 2013), compensating for the high costs of feed processing. Pelleting (temperatures up to $90^{\circ} \mathrm{C}$ and shear force approximately 1 bar) as a kind of hydro-thermal treatment is the most commonly used process for broiler feed production (Zimonja and Svihus, 2005; Abdollahi et al., 2013). More intensive treatments such as expanding (temperatures up to $130^{\circ} \mathrm{C}$ and shear force approximately $40 \mathrm{bar}$ ) or extrusion (temperatures up to $160^{\circ} \mathrm{C}$ and shear force approximately 60 bar) improve sterilisation of the feed and the digestibility of certain nutrients. Due to the heat and pressure applied, some chemical modifications may take place (Svihus and Zimonja, 2011).

Animals at early ages, such as weaning piglets or broiler chicks, are incapable of producing $\alpha$-amylase (Owsley et al., 1986; Noy and Sklan, 1995; Shi-Hou et al., 1998). Additionally, the fact that starch is stored in plants in a crystalline complex structure might impair its digestion in these animals (Cunningham, 1959). The structure of starch can be modified by heat or by physical treatment or a combination thereof, inducing a change in the crystalline structure gelatinisation, thereby facilitating its enzymatic degradation (White et al., 2008; Svihus and Zimonja, 2011). The main aim of a hydro-thermal treatment is to agglomerate smaller feed particles and increased starch gelatinisation through the use of shear force, moisture and heat.

Among the methodologies used to modify feed materials, hydro-thermal technologies are known to exert a major influence on nutrient absorbance in the gut, but this effect strongly depends on the botanical source of grains and seeds (Sun et al., 2006). In addition to the agglomeration of smaller feed particles and the increase of starch gelatinisation, an enhanced hydro-thermal feed treatment has been successful at improving the nutrient value of feed ingredients rich in dietary fat (Kim et al., 2000; Thacker et al., 2005). In conventionally ground, dietary fat-rich feedstuffs, a substantial amount of oil may be encapsulated in the cell wall by the NSP fraction (Kim et al., 2000; Thacker et al., 2005; Kraler et al., 2014). Moreover, the nutrient-encapsulating effect of NSP in fibre-rich industrial by-products is well known (Bedford and Schulze, 1998; Montagne et al., 2003; O’Neill et al., 2014). New literature reports that the improved digestibility and metabolisable energy content (up to $17.5 \%$ ) of wheat bran, an industrial by-products, which are rich in fibre and low in starch, is a result of hydro-thermal or fermentative treatment (Kraler et al., 2014). As a result, it is possible to obtain a higher inclusion level of wheat bran in diets for monogastric animals. Interestingly, these observations were not so pronounced in piglets (Kraler et al., 2015). A possible reason for this phenomenon could be the manner in which the young pigs' digestive system adapts to fibre-rich diets (Högberg 
and Lindberg, 2004; Wetscherek, 2014). Because it is well known, that piglet diets high in dietary fibre are able to modify their intestinal morphology (Schedle et al., 2008a) Improved hygiene is another advantage of the application of hydro-thermal treatments. The heat and pressure produced during the treatment effectively kills microbes, including harmful pathogens (Kraler et al., 2014). The result is an-improvement in the animals' health status and performance (Roth and Kirchgessner, 1998). Above all, swine or poultry is in direct competition with humans concerning foodstuffs. This is due to similar digestive physiology and the similar composition of feedstuffs/foodstuffs as a result thereof. Hence, by applying high amounts of industrial by-products to the monogastric animals' diet, one makes a significant contribution to solving the problem of discrepancies between feed and food. However, high temperatures during feed processing may induce other changes in the feed that may negatively affect its nutritional value. One negative effect may be the formation of complexes between fat and starch in the feed (Zimonja and Svihus, 2005; Thachil et al., 2014). Other negative effects include reduced protein digestibility and the loss of heat-labile components, such as vitamins and enzymes (Opapeju et al., 2006). Nevertheless, hydro-thermal treatments are commonly used techniques for improving nutrient value in diets for pig and poultry (Zimonja and Svihus, 2005; Abdollahi et al., 2013).

Besides hydro-thermal treatments, further techniques like fermentation, germination or soaking show great potential to improve nutrient utilisation in pigs and poultry. Basically a distinction between the fermentation of liquid feed and the fermentation process during wet storage conditions of grains (ensiling), should be done for animal nutrition. In recent years, fermentation of dry feeds was effectively used to improve nutrient digestibility in diets for non-ruminants (Lyberg et al., 2006; Canibe and Jensens, 2012). During fermentation, microorganisms such as lactic acid bacteria convert soluble starch and sugars into organic acids, ethanol and $\mathrm{CO}_{2}$ (Prescott et al., 1996). As a result of the fermentation process, nutrients become more usable for the animal (Jørgensen et al., 2010; Song et al., 2010; Humer et al., 2013; 2014; Kraler et al. 2014).

Unlike wheat bran, maize is highly digestible and one of the most important feed ingredients in swine and poultry diets. In some regions of Europe, storage of maize in a wet form is used to reduce drying costs, so the feeding of fermented maize is widespread in pig production. Similar to wheat bran, the fermentation process which took place while the maize was stored in a wet form improved nutrient digestibility (Humer et al., 2014). Nevertheless, the trypsin inhibitor, which also exists in maize, seems to be completely deactivated by heat but not by ensiling (Brugger et al., 2015). In contrast to these results, Hong et al. (2004) showed a breakdown of the trypsin inhibitor in soy beans and soybean meal caused by solid-state fermentation with Aspergillus oryzae GB-107 with 35\% moisture content. Also in diets for poultry, performance-improving effects were reported by the application of fermented soybean meal (Feng et al., 2007; Wang et al., 2012).

Fermentation of feedstuffs might be of interest to pigs and poultry, as it potentially benefits nutrient and mineral digestibility. Feed treatments including fermentation process or a hydro-thermal application can be a useful tool to improve performance. In contrast, fermentation seems to be more useful than a hydro-thermal treatment in the case of wheat bran (Kraler et al., 2014).

Further advantages of fermentation show, that it increases P-digestibility in growing pigs and therefore reduces the requirement for mineral $\mathrm{P}$ supplementation in swine diets (Humer et al., 2013; Kraler et al., 2014). However, this release can be further enhanced by the addition of exogenous phytase (Humer et al., 2013). Moreover, the amount of nutrients excreted by the animal is reduced when applying these feed treatments, which in turn provides an important contribution to reducing the over-fertilisation of soil in areas which are used intensively for agriculture.

\section{Conclusion}

Up to now, a broad range of tools with different modes of action have been available to improve the efficiency and hence the sustainability of pig and poultry nutrition. Nevertheless, exact knowledge of the mode of action is a prerequisite for the successful application of feed additives in pig and poultry nutrition. Furthermore, information regarding their impact on the nutrient availability in the different feedstuffs is of great importance, in order to formulate diets which cover the animals' requirements and avoid wasting valuable nutrients. The economic aspect related to various feed treatments and feed additives also has to be taken into account. Currently, there are combinations of methods which appear promising in terms of significantly shaping the future of sustainable pig and poultry nutrition. 


\section{References}

AACC (2001): The definition of dietary fiber. Cereal Foods World 46, 112-129.

AOAC (2000): Methods 985.29. Official methods of analysis. $17^{\text {th }}$ ed., W Horwitz, Gaithersburg, MD, USA.

Abdollahi, M.R., Ravindran, V. and B. Svihus (2013): Pelleting of broiler diets: An overview with emphasis on pellet quality and nutritional value. Animal Feed Science and Technology 179, 1-23.

Amad, A.A., Männer, K., Wendler, K.R., Neumann, K. and J. Zentek (2011): Effects of a phytogenic feed additive on growth performance and ileal nutrient digestibility in broiler chickens. Poultry Science 90, 2811-2816.

Amerah, A.M., Ravindran, V. and R.G. Lentle (2009): Influence of insoluble fibre and whole wheat inclusion on the performance, digestive tract development and ileal microbiota profile of broiler chickens. British Poultry Science 50, 366-375.

Awad, W., Ghareeb, K. and J. Böhm (2008): Intestinal structure and function of broiler chickens on diets supplemented with a synbiotic containing Enterococcus faecium and oligosaccharides. International Journal of Molecular Sciences 9, 2205-2216.

Ayoade, D.I., Kiarie, E., Woyengo, T.A., Slominski, B.A., and C.M. Nyachoti (2012): Effect of a carbohydrase mixture on ileal amino acid digestibility in extruded full-fat soybeans fed to finishing pigs. Journal of Animal Science 90, 3842-3847.

Bach Knudsen, K.E. and I. Hansen (1991): Gastrointestinal implications in pigs of wheat and oat fractions. 1. Digestiblity and bulking properties of polysaccharides and other major constitutents. British Journal of Nutrition 65, 217-232.

Bach Knudsen, K.E. (1997): Carbohydrate and lignin contents of plant materials used in animal feeding. Animal Feed Science and Technology 67, 319-338.

Bach Knudsen, K.E. (2001): The nutritional significance of "dietary fibre" analysis. Animal Feed Science and Technology 90, 3-20.

Bedford, M.R., Patience J.F., Classen H.L. and J. Inborr (1992): The effect of dietary enzyme supplementation of rye- and barley-based diets on digestion and subsequent performance in weanling pigs. Canadian Journal of Animal Science 72, 97-105.

Bedford, M.R. (1995): Mechanism of action and potential environmental benefits from the use of feed enzymes. Animal Feed Science and Technology 53, 145-155.
Bedford, M.R. and H. Schulze. (1998): Exogenous enzymes for pigs and poultry. Nutrition Research Reviews $11,91-114$.

Bertschinger, H.U., Eggenberger, E., Jucker, H. and H.P. Pfirter (1979): Evaluation of low nutrient, high fibre diets for the prevention of porcine Escherichia coli enterotoxaemia. Veterinary Microbiology 3, 281-290.

Boguhn, J. and M. Rodehutscord (2010): Effects of nonstarch polysaccharide-hydrolyzing enzymes on performance and amino acid digestibility in turkeys. Poultry Science 89, 505-513.

Böhmer, B.M., Salisch, H., Paulicks, B.R. and F.X. Roth (2009): Echinacea purpurea as a potential immunostimulatory feed additive in laying hens and fattening pigs by intermittent application. Livestock Science 122, $81-85$.

Brenes, A., Jansman, A. and R. Marquard (2004): Recent advances of research in antinutritional factors in legume seeds and oilseeds in monogastric animals. In: Mauzquiz, M., Hill, G.D., Cuadrado, C., Pedrosa, M.M. and C. Burbano (Eds.): Recent Advances of Research in Antinutritional Factors in Legume Seeds and Oilseeds. Wageningen Academic Publishers, Wageningen, 59-71.

Brugger, D., Loibl, P., Schedle, K. and W. Windisch (2015): In-silico and in-vitro evaluation of the potential of maize kernels to inhibit trypsin activity. Animal Feed Science and Technology 207, 289-294.

Bühler, K., Wenk, C., Broz, J. and S. Gebert (2006): Influence of benzoic acid and dietary protein level on performance, nitrogen metabolism and urinary $\mathrm{pH}$ in growing-finishing pigs. Archives of Animal Nutrition 60, 382-389.

Canibe, N., Miettinen, H. and B.B. Jensen (2008): Effect of adding Lactobacillus plantarum or a formic acid containing-product to fermented liquid feed on gastrointestinal ecology and growth performance of piglets. Livestock Science 114, 251-262.

Canibe, N. and B.B. Jensen (2010): Fermented liquid feed - Feed processing has a big impact on microbial degradation of free lysine during fermentation. Livestock Science 133, 120-123.

Chaucheyras-Durand, F. and H. Durand (2010): Probiotics in animal nutrition and health. Beneficial Microbes 1, 3-9.

Cho, J.H., Chen, Y.J., Min, B.J., Kim, H.J. and O.S. Kwon (2006): Effects of essential oils supplementation on growth performance, IgG concentration and fecal 
noxious gas concentration of weaned pigs. Asian-Australasian Journal of Animal Science 19, 80-85.

Cummings, J.H. and G.T. Macfarlane (2007): Gastrointestinal effects of prebiotics. British Journal of Nutrition 87, 145-151.

Cunningham, H.M. (1959): Digestion of starch and some of its degradation products by newborn pigs. Journal of Animal Science 18, 964-975.

DeAngelis, M., Gallo, G., Corbo, M.R., McSweeney, P.L.H., Faccia, M., Giovine, M. and M. Gobbetti (2003): Phytase activity in sourdough lactic acid bacteria: purification and characterization of a phytase from Lactobacillus sanfranciscensis CB 1. International Journal of Food Microbiology 87, 259-270.

Dierick, N. and J. Decuypere (1994): Enzymes and growth in pigs. In: Cole, D.J.A., Wiseman, J. and M.A. Varley (Eds.): Principles of Pig Science. Nottingham University Press, Nottingham, 169-195.

DLG (2014): Feedstuff Database. http://www.dlg.org/futtermitteldatenbank.html (accessed on 10 October 2014).

Domeneghini, C., DiGiancamillo, A. Arrighi S. and G. Bosi (2006): Gut-trophic feed additives and their effects upon the gut structure and intestinal metabolism. State of the art in the pig, and perspectives towards humans. Histology Histopathology 21, 273-283.

Drochner, W., Kerler, A. and B. Zacharias (2004): Pectin in pig nutrition, a comparative review. Journal of Animal Physiology and Animal Nutrition 88, 367-380.

Eder, K., Nonn, H., Kluge, H. and S. Peganova (2003): Tryptophan requirement of growing pigs at various body weights. Journal of Animal Physiology and Animal Nutrition 87, 336-346.

Emiola, I.A., Opapeju, F.O., Slominski, B.A. and C.M. Nyachoti (2009): Growth performance and nutrient digestibility in pigs fed wheat distillers dried grains with solubles-based diets supplemented with a multicarbohydrase enzyme. Journal of Animal Science 87, 2315-2322.

Fang, J., Yan F.Y., Kong, X.F., Ruan, Z., Liu, Z.Q. and R.L. Huang (2009): Dietary supplementation with Acanthopanax senticosusu extract enhances gut health in weanling piglets. Livestock Science 123, 268-275.

FEFAC (2009): Environment report. $1^{\text {st }}$ Edition, European Feed Manufacturers Federation, Brussels.

Feng, J., Liu, X., Xu, Z.R., Lu, J.P and Y.Y. Liu. (2007): Effect of fermented soybean meal on intestinal morphology and digestive enzyme activities in weaned piglets. Digestive Diseases and Sciences 52, 1845-1850.
Fritts, C.A., Kersey, J.H., Motl, M.A., Kroger, E.C., Yan, F., Si, J., Jiang, Q., Campos, M.M., Waldroup, A.L. and P.W. Waldroup (2000): Bacillus subtilis C-3102 (Calsporin) improves live performance and microbiological status of broiler chickens. Journal of Applied Poultry Research 9, 149-155.

Fuller, R. (1989): Probiotics in man and animals. Journal of Applied Bacteriology 166, 365-378.

Gaggia, F., Matrarelli, P. and B. Biavati (2010): Probiotics and prebiotics in animal feeding for safe food production. International Journal of Food Microbiology 141, Supplement 1, 15-28.

Gibson, G.R. and M.B. Roberfroid (1995): Dietary modulation of the human colonic microbiota. Introducing the concept of prebiotics. Journal of Nutrition 125, 1401-1412.

Glitsø, L.V., Brunsgaard, G., Højsgaard, S., Sandström, B. and K.E. Bach Knudsen (1998): Intestinal degradation in pigs of rye dietary fibre with different structural characteristics. British Journal of Nutrition 80, 457-468.

González-Alvarado, J.M., Jiménez-Moreno, E., Valencia, D.G., Lázaro, R. and G.G. Mateos (2008): Effects of fiber source and heat processing of the cereal on the development and $\mathrm{pH}$ of the gastrointestinal tract of broilers fed diets based on corn or rice. Poultry Science 87, 1779-1795.

González-Alvarado, J.M., Jiménez-Moreno, E., GonzálezSánchez, D., Lázaro, R. and G.G. Mateos (2010): Effect of inclusion of oat hulls and sugar beet pulp in the diet on productive performance and digestive traits of broilers from 1 to 42 days of age. Animal Feed Science and Technology 162, 37-46.

Grünewald, K.H., Steuer, G. and G. Flachowsky (2006): Praxiserhebungen zum Jodgehalt im Mischfutter. In: Rodehutscord, M. (Ed.): 9. Tagung Schweine- und Geflügelernährung, 28.-30. November 2006, Institut für Agrar- und Ernährungswissenschaften, Universität Halle-Wittenberg, 176-178. ISBN 3-86010-833-6.

Hadorn, R. and C. Wenk (1996): Effect of different sources of dietary fibre on nutrient and energy utilization in broilers. 1. Characterization of the diets, growth performance and nutrient utilization. Archiv Geflügelkunde 60, 14-21.

Hansen, M.J., Chwalibog, A., Tauson, A.H. and E. Sawosz (2006): Influence of different fibre sources on digestibility and nitrogen and energy balances in growing pigs. Archives of Animal Nutrition 60, 390-401. 
Högberg, A. and J.E. Lindberg (2004): Influence of cereal non-starch polysaccharides and enzyme supplementation on digestion site and gut environment in weaned piglets. Animal Feed Science and Technology 116, 113-128.

Hong, K.J., Lee, C.H. and S.W. Kim (2004): Aspergillus oryzae $G B-107$ fermentation improves nutritional quality of food soybeans and feed soybean meals. Journal of Medicinal Food 7, 430-435.

Hoffman-Pennesi, D. and C. Wu (2010): The effect of thymol and thyme oil feed supplementation on growth performance, serum antioxidant levels, and cecal Salmonella population in broilers. The Journal of Applied Poultry Research 19, 432-443.

Huang, C., Qiao, S., Li, D., Piao, X. and J. Ren (2004): Effects of lactobacilli on the performance, diarrhea incidence, VFA concentration and gastrointestinal microbial flora of weaning pigs. Asian-Australasian Journal of Animal Science 17, 401-409.

Humer, E., Rohrer, E., Windisch, W., Wetscherek, W., Schwarz, C., Jungbauer, L. and K. Schedle (2015a): Gender-specific effects of a phytogenic feed additive on performance, intestinal physiology and morphology in broiler chickens. Journal of Animal Physiology and Animal Nutrition 99, 788-800.

Humer, E., Schwarz, C. and K. Schedle (2015b): Phytate in pig and poultry nutrition. Journal of Animal Physiology and Animal Nutrition 99, 605-625.

Humer, E., Wetscherek, W., Schwarz, C. and K. Schedle (2013): Effect of maize conservation technique and phytase supplementation on total tract apparent digestibility of phosphorus, calcium, ash, dry matter, organic matter and crude protein in growing pigs. Animal Feed Science and Technology 185, 70-77.

Humer, E., Wetscherek, W., Schwarz, C. and K. Schedle (2014): Effects of maize conservation techniques on the apparent total tract nutrient and mineral digestibility and microbial metabolites in the faeces of growing pigs. Animal Feed Science and Technology 197, 176-184.

Jørgensen, H., Zhao, X.Q. and B.O. Eggum (1996): The influence of dietary fibre and environmental temperature on the development of the gastrointestinal tract, digestibility, degree of fermentation in the hind-gut and energy metabolism in pigs. British Journal of Nutrition 75, 365-378.

Kabir, S.M.L. (2009): The role of probiotics in the poultry industry. International Journal of Molecular Sciences $10,3531-3546$.
Kelly, D., Begbie, R. and T.P. King (1994): Nutritional influences on interactions between bacteria and the small intestinal mucosa. Nutrition Research Reviews 7 , 233-257.

Kim, I.H., Hancock, J.D., Hines, R.H. and T.L. Gugle (2000): Roasting and extruding affect nutrient utilization from soybeans in 5 and $10 \mathrm{~kg}$ nursery pigs. AsianAustralasian Journal of Animal Science 13, 205-206.

Kluth, H. and M. Rodehutscord (2006): Comparison of amino acid digestibility in broiler chickens, turkeys, and peking ducks. Poultry Science 85, 1953-1960.

Kommera, S.K., Mateo, R.D., Neher, F.J. and S.W. Kim (2006): Phytobiotics and organic acids as potential alternatives to the use of antibiotics in nursery pig diets. Asian-Australasian Journal of Animal Science 19, 17841789.

Kornegay, E.T. (2001): Digestion of phosphorus and other nutrients: The role IU of phytases and factors influencing their activity. In: Bedford, M.R. and G.G. Partidge (Eds): Enzymes in farm animal nutrition. CAB International, London, 237-271.

Kraler, M., Schedle, K., Domig, K.J., Heine, D., Michlmayr, H. and W. Kneifel (2014): Effects of fermented and extruded wheat bran on total tract apparent digestibility of nutrients, minerals and energy in growing pigs. Animal Feed Science and Technology 197, 121-129.

Kraler, M., Schedle, K., Schwarz, C., Domig, K.J., Pichler, M., Oppeneder, A., Wetscherek, W., Prückler, M., Pignitter, M., Pirker, K.F., Somoza, V., Heine, D. and W. Kneifel (2015): Fermented and extruded wheat bran in piglet diets: Impact on performance, intestinal morphology, microbial metabolites in chyme and blood lipid radicals. Archives of Animal Nutrition 69, 378-398.

Kreuzer, M., Heindl, U., Roth-Maier, D.A. and M. Kirchgessner (1991): Cellulose fermentation capacity of the hindgut and nitrogen turnover in the hindgut of sows as evaluated by oral and intracecal supply of purified cellulose. Archiv Tierernährung 41, 359-372.

Kroismayr, A., Schedle, K., Sehm, J. and M.W. Pfaffl (2008a): Effects of antimicrobial feed additives on gut microbiology and blood parameters of weaned piglets. Die Bodenkultur 59, 111-120.

Kroismayr, A., Sehm, J., Pfaffl, M.W., Schedle, K., Plitzner, C. and W. Windisch (2008b): Effects of avilamycin and essential oils on mRNA expression of apoptotic and inflammatory markers and gut morphology of piglets. Czech Journal of Animal Science 53, 377-387. 
Kozlowska, H., Honke, J., Sadowska, J., Frias, J. and C. Vidal-Valverde (1996): Natural fermentation of lentils: Influence of time, concentration and temperature on the kinetics of hydrolysis of inositol phosphates. Journal of the Science of Food and Agriculture 71, 367-375.

Leytem, A.B. and P.A. Thacker (2010): Phosphorus utilization and characterization of excreta from swine fed diets containing a variety of cereal grains balanced for total phosphorus. Journal of Animal Science 88, 1860-1867. Lopez, H.W., Vallery, F., Levrat-Verny, M.A., Coudray, C., Demigné, C. and C. Rémésy (2000): Dietary phytic acid and wheat bran enhance mucosal phytase activity in rat small intestine. Journal of Animal Science 130, 2020-2025.

Lyberg, K., Lundh, T., Pedersen, C. and J.E. Lindberg (2006): Influence of soaking, fermentation and phytase supplementation on nutrient digestibility in pigs offered a grower diet based on wheat and barley. Animal Science 82, 853-858.

Mair, C., Plitzner, C., Domig, K.J., Schedle, K. and W. Windisch (2010a): Impact of inulin and a multispecies probiotic formulation on performance, microbial ecology and concomitant fermentation patterns in newly weaned piglets. Journal of Animal Physiology and Animal Nutrition 94, e164-e177.

Mair, C., Plitzner, C., Pfaffl, M.W., Schedle, K., Meyer, H.H.D. and W. Windisch (2010b): Inulin and probiotics in newly weaned piglets: Effects on intestinal morphology, mRNA expression levels of inflammatory marker genes and haematology. Archives of Animal Nutrition 64, 304-321.

McDonald, D.E., Pethick, D.W., Mullan, B.P. and D.J. Hampson (2001): Increasing viscosity of the intestinal contents alters small intestinal structure and intestinal growth, and stimulates proliferation of enterotoxigenic Escherichia coli in newly-weaned pigs. British Journal of Nutrition 86, 487-498.

Medel, P., Baucells, F., Gracia, M.I. and C. De Blas (2002): Processing of barley and enzyme supplementation in diets for young pigs. Animal Feed Science and Technology 95, 113-122.

Montagne, L., Pluske, J.R. and D.J. Hampson (2003): A review of interactions between dietary fibre and the intestinal mucosa, and their consequences on digestive health in young non-ruminant animals. Animal Feed Science and Technology 108, 95-117.

Mountzouris, K.C., Tsirtsikos, P., Kalamara, E., Nitsch, S., Schatzmayr, G. and K. Fegeros (2007): Evaluation of the efficacy of a probiotic containing Lactobacillus, Bifidobacterium, Enterococcus, and Pediococcus strains in promoting broiler performance and modulating cecal microflora composition and metabolic activities. Poultry Science 86, 309-317.

Metzler-Zebeli, B.U., Hooda, S., Zijlstra, R.T., Mosenthin, R. and M.G. Gänzle (2010): Dietary supplementation of viscous and fermentable non-starch polysaccharides (NSP) modulates microbial fermentation in pigs. Livestock Science 133, 95-97.

Mueller, K., Blum, N.M. and A.S. Mueller (2013): Examination of the anti-inflammatory, antioxidant, and xenobiotic-inducing potential of broccoli extract and various essential oils during a mild DSS-induced colitis in rats. Gastroenterology 2013, 1-14.

Mussatto, S.I. and I.M. Mancilha (2007): Non-digestible oligosaccharides: A review. Carbohydrate Polymers 68, 587-597.

Najafi, P. and M. Torki (2010): Performance, blood metabolites and immunocompetence of broiler chicks fed diets included essential oils of medicinal herbs. Journal of Animal and Veterinary Advances 9, 1164-1168.

Niemann, H., Kuhla, B. and G. Flachowsky (2011): Perspectives for feed-efficient animal production. Journal of Animal Science 89, 4344-4363.

Netherwood, T., Gilbert, H.J., Parker, D.S. and A.G. O'Donnell (1999): Probiotics shown to change bacterial community structure in the avian gastrointestinal tract. Applied and Environmental Microbiology 65, 5134-5138.

Nisbet, D.J. (1998): Use of competitive exclusion in food animals. Journal of the American Veterinary Medical Association 213, 1744-1746.

Nolan, A., McDonnell, K., Devlin, G.J., Carroll, J.P. and J. Finnan (2010): Economic analysis of manufacturing costs of pellet production in the Republic of Ireland using nonwoody biomass. Open Renewable Energy Journal 3, 1-11.

Noy, Y. and D. Sklan (1995): Digestion and absorption in the young chick. Poultry Science 74, 366-373.

NRC (2012): Nutrient requirements of swine. National Academies Press, Washington.

O'Neill, H., Smith, J.A. and M.R. Bedford (2014): Multicarbohydrase enzymes for non-ruminants. Asian-Australasian Journal of Animal Sciences 37, 290-301.

Opapeju, F.O., Golian, A., Nyachoti, C.M. and L.D. Campbell (2006): Amino acid digestibility in dry extruded-expelled soybean meal fed to pigs and poultry. Journal of Animal Science 84, 1130-1137. 
Overland, M., Granli, T., Kjos, N.P., Fjetland, O., Steien, S.H. and M. Stokstad (2000): Effect of dietary formates on growth performance, carcass traits, sensory quality, intestinal microflora, and stomach alterations in growing-finishing pigs. Journal of Animal Science 78, 1875-1884.

Owsley, W.F., Orr, D.E. Jr. and L.F. Tribble (1986): Effects of age and diet on the development of the pancreas and synthesis and secretion of pancreatic enzymes in the young pig. Journal of Animal Science 63, 497-504.

Parker, R.B. (1974): Probiotics, the other half of the antibiotic story. Animal Nutrition Health 29, 4-8.

Partanen, K., Siljander-Rasi, H., Alaviuhkola, T., Suomi, K. and M. Fossi (2002): Performance of growing-finishing pigs fed medium- or high-fibre diets supplemented with avilamycin, formic acid or formic acid-sorbate blend. Livestock Production Science 73, 139-152.

Plitzner, C., Schedle, K., Wagner, V., Ettle, T. and W. Windisch (2006): Influence of adding 0.5 or 1.0 percent of benzoic acid on growth performance and urinary parameters of fattening pigs. Slovak Journal of Animal Sciences 39, 69-73.

Pluske, J.R., Hampson, D.J. and I.H. Williams (1997): Factors influencing the structure and function of the small intestine in the weaned pig: A review. Livestock Production Science 51, 215-236.

Pommerening-Röser, A. and H.P. Koops (2005): Environmental $\mathrm{pH}$ as an important factor for the distribution of urease positive ammonia-oxidation bacteria. Microbiological Research 160, 1-27.

Prescott, L.M., Harley, J.P. and D.A. Klein (1996): Microbiology. WCB Publishers, London.

Roller, M., Rechkemmer, G. and B. Watzl (2004): Prebiotic inulin enriched with oligofructose in combination with the probiotics Lactobacillus rhamnosus and Bifidobacterium lactis modulates intestinal immune functions in rats. Journal of Nutrition 134, 153-156.

Roth, F.X. and M. Kirchgessner (1998): Organic acids as feed additives for young pigs: Nutritional and gastrointestinal effects. Journal of Animal and Feed Sciences 8, 25-33.

Sander, S.J., Bullermann, J., Arlinghaus, M., Verspohl, J. and J. Kamphues (2012): The influence of grinding intensity and compaction of diets on the microbial community in the gastrointestinal tract of young pigs. Journal of Animal Science 90, Supplement 4, 16-18.

Sauer, W.C., Mosenthin, R., Ahrens, F. and L.A. den Hartog (1991): The effect of source of fiber on ileal and fecal amino acid digestibility and bacterial nitrogen ex- cretion in growing pigs. Journal of Animal Science 69, 4070-4077.

Sauvant, D., Perez, J.M. and G. Tran (2004): Tables of composition and nutritional value of feed materials. INRA Editions. Wageningen Academic Publishers, Wageningen.

Schedle, K., Humer, E. and C. Mair (2013): Eiweißalternativen zu Sojaextraktionsschrot: Einsatzmöglichkeiten und Limitierungen in der Mastschweinefütterung - Ein Review. Tierärztliche Umschau 68, 336-342.

Schedle, K., Mair, C. and R. Leitgeb (2010a): Zootechnical performance and carcass characteristics of broiler chicks fed different kinds and concentrations of distillers dried grains with solubles (DDGS). Die Bodenkultur 61, 37-48.

Schedle, K., Mair, C. and W. Windisch (2010b): Experimentelle Untersuchungen zur Wirkung von Weizentrockenschlempe auf die Mast-und Schlachtleistung, Trockenmasse und Ammoniak im Colonchymus sowie Harnstoff im Blutplasma bei Mastschweinen. Züchtungskunde 82, 303-315.

Schedle, K., Pecina, J., Punz, C. and C. Mair (2012): Inclusion of NSP-hydrolyzing enzymes in diets for grower-finisher pigs containing two levels of distillers dried grains with solubles. Large Animal Review 18, 129-134.

Schedle, K., Freudenberger, G., Leitgeb, R. and C. Schwarz (2014): Impact of NSP-hydrolyzing enzymes in DDGS supplemented diets for broilers on performance, as well as energy and $\mathrm{N}$ utilization. In: Proceedings of the Society of Nutrition Physiology, 105. ISBN 978-3-76904107-1.

Schedle, K., Pfaffl, M.W., Plitzner, C., Meyer, H.H.D. and W. Windisch (2008a): Effect of insoluble fibre on intestinal morphology and mRNA expression pattern of inflammatory, cell cycle and growth marker genes in a piglet model. Archives of Animal Nutrition 62, 427-438.

Schedle, K., Plitzner, C., Ettle, T., Zhao, L., Domig, K.J. and W. Windisch (2008b): Effects of insoluble dietary fibre differing in lignin on performance, gut microbiology, and digestibility in weanling piglets. Archives of Animal Nutrition 62, 141-151.

Schrezenmeir, J. and M. de Vrese. (2001): Probiotics, prebiotics, and synbiotics-approaching a definition. American Journal of Clinical Nutrition 73, 361s-364s. Selle, P.H. and V. Ravindran (2008): Phytate-degrading enzymes in pig nutrition. Livestock Science 113, 99-122.

Simon, O. (2010): An interdisciplinary study on the mode of action of probiotics in pigs. Journal of Animal and Feed Sciences 19, 230-243. 
Shi-Hou, J., Corless, A. and J.L. Sell (1998): Digestive system development in post-hatch poultry. World's Poultry Science Journal 54, 335-345.

Song, Y.S., Pérez, V.G.P., Pettigrew, J.E., Martinez-Villaluenga, C. and E.G. de Mejia (2010): Fermentation of soybean meal and its inclusion in diets for newly weaned pigs reduced diarrhea and measures of immunoreactivity in the plasma. Animal Feed Science and Technology 159, 42-50.

Sun, T., Lærke, H.N., Jørgensen, H. and K.E. Bach Knudsen (2006): The effect of extrusion cooking of different starch sources on the in vitro and in vivo digestibility in growing pigs. Animal Feed Science and Technology 131, 67-86.

Svihus, B. and O. Zimonja (2011): Chemical alterations with nutritional consequences due to pelleting animal feeds: A review. Animal Production Science 51, 590-596.

Thachil, M.T., Chouksey, M.K. and V. Gudipati (2014): Amylose-lipid complex formation during extrusion cooking: Effect of added lipid type and amylose level on corn-based puffed snacks. International Journal of Food Science and Technology 49, 309-316.

Thacker, P.A., Willing, B.P. and V.J. Racz (2005): Performance of broiler chicks fed wheat-based diets supplemented with combinations of non-extruded or extruded canola, flax and peas. Journal of Animal and Veterinary Advances 4, 902-907.

Thompson, P.B. and A. Nardone (1999): Sustainable livestock production: Methodological and ethical challenges. Livestock Production Science 61, 111-119.

Van Nevel, C J., Dierick, N.A., Decuypere, J.A. and S.M. De Smet (2006): In vitro fermentability and physicochemical properties of fibre substrates and their effect on bacteriological and morphological characteristics of the gastrointestinal tract of newly weaned piglets. Archives of Animal Nutrition 60, 477-500.

Vranjes, M.V. and C. Wenk (1995): The influence of extruded vs. untreated barley in the feed, with and without dietary enzyme supplement on broiler performance. Animal Feed Science and Technology 54, 21-32.

Von Engelhardt, W., Rönnau, K., Rechkemmer, G. and T. Sakata (1989): Absorption of short-chain fatty acids and their role in the hindgut of monogastric animals. Animal Feed Science and Technology 23, 43-53.
Wang, L.C., Wen, C. and Z.Y. Jiang (2012): Evaluation of the partial replacement of high-protein feedstuff with fermented soybean meal in broiler diets. Journal of Applied Poultry Research 21, 849-855.

Wenk, C. (2001): The role of dietary fibre in the digestive physiology of the pig. Animal Feed Science and Technology 90, 21-33.

Wetscherek, W. (2014): Use of DDGS in diets for piglets and fattening. In: Arbeitsgemeinschaft für Lebensmittel-, Veterinär- und Agrarwesen, Tagungsbericht 2014 „Angewandte Forschung - gibt es neue Wege?“, 153155. ISSN 1606-612X.

White, G.A., Doucet, F.J., Hill, S.E. and J. Wiseman (2008): Physicochemical changes to starch granules during micronisation and extrusion processing of wheat, and their implications for starch digestibility in the newly weaned piglet. Animal 2, 1312-1323.

Widmer, M.R., McGinnis, L.M., Wulf, D.M. and H.H. Stein (2008): Effects of feeding distillers dried grains with solubles, high-protein distillers dried grains, and corn germ to growing-finishing pigs on pig performance, carcass quality, and the palatability of pork. Journal of Animal Science 86, 1819-1831.

Williams, B.A., Verstegen, M.W.A. and S. Tamminga (2001): Fermentation in the large intestine of singlestomached animals and its relationship to animal health. Nutrition Research Reviews 14, 207-227.

Windisch, W., Schedle, K., Plitzner, C. and A. Kroismayr (2008): Use of phytogenic products as feed additives for swine and poultry. Journal of Animal Science 86, E140-E148.

Widyaratne, G.P., Patience, J.F. and R.T. Zijlstra (2009): Effect of xylanase supplementation of diets containing wheat distiller's dried grains with solubles on energy, amino acid and phosphorus digestibility and growth performance of grower-finisher pigs. Canadian Journal of Animal Science 89, 91-95.

Zimonja, O. and B. Svihus (2005): A comparison of pelleting tand expander treatment on nutritional value of a broiler diet containing two different fat sources. In: Proceedings of the $15^{\text {th }}$ European Symposium on poultry nutrition, 473-475. 